\author{
Review Article
}

\title{
EFFECTIVE MANAGEMENT OF HYPOTHYROIDISM BY USING AYURVEDIC INTERVENTIONS: A CASE REPORT
}

\section{Bhawna Walia*, Manish Grover, Ajeet Pratap Singh}

Shuddhi Ayurveda, Jeena Sikho Lifecare Pvt. Ltd. Zirakpur, Punjab, India

\section{Article info \\ Article History: \\ Received: 08-08-2021 \\ Revised : 21-08-2021 \\ Accepted: 01-09-2021 \\ Published: 18-09-2021}

\section{KEYWORDS:}

Hypothyroidism, Kapha, Avatu, Granthi Shoth.

\begin{abstract}
Hypothyroidism is an endocrine disorder that mainly occurs due to insufficient thyroid gland stimulation or primary gland failure by the pituitary or hypothalamus gland. Symptoms of hypothyroidism include fatigue, gastric trouble, face puffiness with edematous eyelids, retarded nail growth, weight gain, hoarseness of voice, decreased libido, pallor, dry skin, dry hair, alopecia, constipation, abnormal menstrual cycle, muscle cramps, myalgia etc. A 30-year-old married Hindu, non-alcoholic, non-smoking male patient visited OPD of Shuddhi Ayurveda Clinic, Jeena Sikho Lifecare Pvt. Ltd. Noida on 18 November 2020 with known case of subclinical hypothyroidism. On the basis of clinical diagnosis and laboratory investigations, Ayurvedic medicines having action on thyroid gland and digestion improvement were prescribed for over a period of six months. After this Ayurvedic medicinal treatment for four months i.e. from November 2020 to February 2021, significant results were noted in terms of reduction in level of increased TSH. TSH level was significantly reduced from $181 \mu \mathrm{IU} / \mathrm{ml}$ to $0.11 \mu \mathrm{IU} / \mathrm{ml}$ within two months of Ayurvedic treatment. Then, there was a mild increase in the TSH level when patient was tested for TFT after four months i.e. on $21^{\text {st }}$ of June 2021 , investigated level of TSH was $5.59 \mu \mathrm{IU} / \mathrm{ml}$. Overall, a satisfactory result was observed in patient clinical conditions proving significant efficacy of Ayurvedic treatment.
\end{abstract}

\section{INTRODUCTION}

The very first endocrine gland to develop in humans was thyroid gland which is the most vascularized organ in the body located in the neck anteriorly between the C5 and T1 vertebrae and deep in the platysma, sternothyroid, and sternohyoid muscles. It is a bilobular soft reddish organ having $\mathrm{H}$ shaped structure. The lobes, right and left are connected by isthmus. Thyroid weighs about $15-20 \mathrm{~g}$ and usually heavier in males than females whereas it weighs about 1 in a newborn which increases 1 gm per year until the age of $15^{[1]}$. The gland is known for its hormones which are produced by the hypothalamus or pituitary gland which include tri-iodothyronine (T3) and tetra-iodothyronine (T4) where T3 is functionally

\begin{tabular}{|l|l|}
\hline \multicolumn{3}{|c|}{ Access this article online } \\
\hline Quick Response Code & https://doi.org/10.47070/ijapr.v9i8.1976 \\
\hline & $\begin{array}{l}\text { Published by Mahadev Publications } \\
\text { (Regd.) publication licensed under a } \\
\text { Creative Commons Attribution- } \\
\text { NonCommercial-ShareAlike } \\
\text { International (CC BY-NC-SA 4.0) }\end{array}$ \\
\hline
\end{tabular}

more active. These are formed within the follicular cells of the thyroid gland and are released into the systematic circulation in response to Thyroid Stimulating Hormone (TSH). The trace element iodine is required for the synthesis of thyroid hormone. Any abnormality in the thyroid gland and its morphology may lead to various thyroid disorders which are the most common endocrine disorders with the occurrence rate of 42 million of the total population and $11 \%$ in India[2,3].

The primary reason of disease genesis in the modern times is drastic changes in the lifestyle and dietary habits such as sedentary lifestyle with unhealthy eating habits ${ }^{[4]}$. Thyroid actively carries the process of metabolism but lack or resistance of body tissue to this hormone with respect to metabolic demand results in hypothyroidism[5]. It is an endocrine disorder that mainly occurs due to insufficient thyroid gland stimulation or primary gland failure by the pituitary or hypothalamus gland. There can be various causes of hypothyroidism such as iodine deficiency, autoimmune, iatrogenic and transient thyroiditis ${ }^{[6]}$. It is the most common disease found in every third 
individual in today's world. Hypothyroidism is mainly of three types i.e., primary, secondary and tertiary where primary hypothyroidism is the commonest type occurs due to abnormalities in thyroid gland[7]. Secondary and tertiary hypothyroidism occurs due to malfunctioning of pituitary and hypothalamus gland [8]. Symptoms of hypothyroidism include fatigue, gastric trouble, face puffiness with edematous eyelids, retarded nail growth, weight gain, hoarseness of voice, decreased libido, pallor, dry skin, dry hair, alopecia, constipation, abnormal menstrual cycle, muscle cramps, myalgia etc. Hypothyroidism can also lead to dyslipidemia, hypertension, cognitive impairment, infertility and neuromuscular dysfunction. As per WHO reports there are about 2 billion people are found to be iodine deficient worldwide[9].

A type of hypothyroidism called subclinical hypothyroidism is the condition in which the patient is diagnosed with normal T3 and T4 level but raised TSH levels up to $10 \mathrm{IU} / \mathrm{dl}$ with specific cardinal symptoms [10-13]. The terms "Galaganda" and "Avatu granthi alapa shrota" (enlarged thyroid gland) are mentioned in many ancient Ayurvedic texts like Charaka, Sushrutha and Asthang hrudaya which are related to disorders of thyroid gland. Although there are no direct references available in Ayurveda regarding hyper- or hypo production of the thyroid hormone, but as the name suggests it is the manifestation of swelling in or around the neck, so it can be considered as goiter and thyroidism. Galaganda is attributed to the hypo functioning of metabolic system i.e., Agni. There are five classifications of hypothyroidism which are entirely based on its causes i.e. Vata, Pita, Kapha or urinary tract infections (mostly in females) and finally the goiter (advanced stage of hypothyroidism induced by Kapha). Hypothyroidism mainly occurs due to vitiation in Vata and Kapha doshas and comes under Anukta vikara and is considered as Vata-kafaj dushtijanya vhadhi with indications like Kapha doshas, Rasa dhatvangni and Rasa dhatu ${ }^{[14-19] .}$

Galaganda was first described in Atharva Veda by the name Apachi. It is mentioned under 20 Sleshma Vikaras by Charaka. According to Sushruta in Sareera Sthana, the sixth layer of the skin named Rohini is served as the seat of Galaganda. As per Nidaan Sthana, it is present anteriorly to the neck as two encapsulated swellings either small or big present in hanging position whereas Aacharya Charaka described the disease as a single swelling. Aacharya Bhela mentioned that it is one of the diseases that is more commonly found in people of the Eastern part of the country and who consume high fish diet. According to Harita Samhita, contaminated water and infection are two primary causes of this disease. In addition, Kashyapa Samhita mentioned that people of cold, rainy, damp and densely covered areas with stagnant water are more likely to have symptoms of this disease[20]. Ayurvedic treatment of this disease is initiated by clearing of the blocked channels followed by an oral therapy and Rasayana (rejuvenative) therapy. The basic principle used in Ayurvedic line of treatment is of Galaganda "Saamanya Vishesh Siddhanta" which indicates the meaning that the disease is aggravated by similar condition and alleviated by dissimilar conditions. For example, Kapha inhibiting drugs are used to decrease Kapha, pitta enhancing drugs are used to increase Pitta whereas Meda (fat) neutralizing drugs are used to lower down the Meda which ultimately helps in restoring the homeostasis along with metabolic activity which were disturbed by blockage of channels by Kapha [21].

\section{Case Report}

A 30-year-old married Hindu, non-alcoholic, non-smoking male patient visited OPD of Shuddhi Ayurveda Clinic, Jeena Sikho Lifecare Pvt. Ltd. Noida on 18 November 2020, with chief complaints of fatigue, throat irritation, temporal joint pain, loss of appetite, gastric trouble, nightfall, increased levels of $\mathrm{TSH}$, abnormal LFT, irregular thyroid, body weakness and stiffening of joints. The patient was suffering from these symptoms from the past one and half year with no any family history of such disease. Patient came with the previous report for his thyroid profile (T3, T4, TSH) which was done on 1 March 2020. Reports showed high level of TSH i.e. $181 \mu \mathrm{IU} / \mathrm{mL}$. T3 and T4 was within normal range i.e. $21.85 \mathrm{ng} / \mathrm{dl}$ and $2.05 \mu \mathrm{g} / \mathrm{dl}$. From this reports it was clear that he is suffering from subclinical hypothyroidism. The patient was on allopathic medication for the same disease but didn't get any relief.

\section{Patient Information}

\section{Presenting Complaints}

The chief complaints of the patient were fatigue, muscle pain, gastric trouble.

\section{Medical, family and psychosocial history including genetic information}

The patient represented no history of drug intake or any other kind of addiction. Patient had a previous disease history of typhoid, dengue, renal stone and hemorrhoids for which he took allopathic treatment and undergone surgeries. In the family, there was no history of any such or other kind of chronic disease.

\section{Relevant past interventions and their outcomes}

The patient had undergone through the surgical procedures named haemorrhoidectomy and percutaneous nephrolithotomy (PCNL) for the problem of hemorrhoid and renal stone respectively. Also, the patient consulted Shuddhi Ayurveda Clinic for the first time for the chief complaint of Hypothyroidism. 


\section{Clinical Findings}

\section{Physical and Systemic Examination}

The patient was systemically examined for his bowel (frequency and evacuation), appetite and digestion, gas, acidity, eyes, urine, sleep and mind. From the assessment it was observed that:

- Bowel was soft, yellowish and mixed with mucus but evacuated incompletely.

- Felling of anorexia with episodes of tightness before the next meal.
- Severe bloating with difficulty in passing of gas.

- The frequency of urination was 5-6 times a day.

- Short tempered along with mood swings, stress and restlessness.

\section{Clinical Assessment}

The patient was clinically assessed by Jeebha pariksha (tongue examination) and Naadi parisksha (pulse examination).

\section{Jeebha Pariksha (Tongue examination)}

\begin{tabular}{|l|l|l|l|l|}
\hline $\mathbf{1}^{\text {st }}$ Month & $\mathbf{2}^{\text {nd }}$ Month & $\mathbf{3}^{\text {rd }}$ Month & $\mathbf{4}^{\text {th }}$ Month & $\mathbf{5}^{\text {th }}$ Month \\
\hline $18 / 11 / 2020$ & $15 / 01 / 2021$ & $10 / 02 / 2021$ & $11 / 03 / 2021$ & $22 / 05 / 2021$ \\
\hline $\begin{array}{l}\text { Pinkish cracked lines } \\
\text { appeared }\end{array}$ & $\begin{array}{l}\text { The crack lines } \\
\text { reduced }\end{array}$ & $\begin{array}{l}\text { Slightly pinkish } \\
\text { color appeared }\end{array}$ & $\begin{array}{l}\text { Appears normal } \\
\text { with no coating }\end{array}$ & $\begin{array}{l}\text { Appears normal } \\
\text { with no coating }\end{array}$ \\
\hline
\end{tabular}

\section{Naadi Pariksa (Pulse Examination)}

\begin{tabular}{|l|l|l|l|l|l|}
\hline \multirow{2}{*}{ Naadi } & $\mathbf{1}^{\text {st }}$ Month & $2^{\text {nd }}$ Month & $3^{\text {rd }}$ Month & $\mathbf{4}^{\text {th }}$ Month & $5^{\text {th }}$ Month \\
\cline { 2 - 6 } & $18 / 11 / 2020$ & $15 / 01 / 2021$ & $10 / 02 / 2021$ & $11 / 03 / 2021$ & $22 / 05 / 2021$ \\
\hline Vata & Moderate $(++)$ & Moderate $(++)$ & Moderate(++) & Average (+) & Average (+) \\
\hline Pita & High (+++) & Moderate (++) & Moderate(++) & Average (+) & Average (+) \\
\hline Kapha & Moderate (++) & Moderate (++) & Average (+) & Average (+) & Average (+) \\
\hline
\end{tabular}

Indications: $(+++)$ High force (Bala), $(++)$ Moderate force $($ Bala $),(+)$ Average force $($ Bala).

\section{Dashvidh Pariksha}

Prakriti (physical constitution):- Vatakaphaj

Vikruti (pathological condition):- Vyadhimadhyambala

Dosha (deranged regulatory functional factors of the body):- Vata pitta dusti

Dushya (deranged major structural components of the body):- Rasa and Raktadusti

Sthana (site of localization):- Amashyagata

Agni (digestive/metabolic factors):- Mandagani

Srotas (structural or functional channels):- Annavahashrotas and Raktavahashrotas

Avastha (stage of disease):- Jirnaavastha

Rogamarga (pathway of disease manifestation):- Abhyantarmarga

Sadhyaasadhyata (prognosis):- Shadhyaaswastha

Sara (excellence of tissues):- Raktasara

Samhanana (body compactness):- Madhyamsamhanna

Pramana (measurements of body parts):- Madhyampraman

Satmya (homologation):- Alpasatmya

Sattva (mental constitution):- Avara sattva

Aharashakti (capacity to ingest food and capacity to digest and assimilate the food):- Madhyamshakti

Vyayamashakti (capacity to exercise):- Avara (poor)

Vaya (age): Madhyamyuvanavastha

\section{Laboratory Assessment}

Patient was investigated for assessing the functioning of thyroid gland by Thyroid function test previously in March 2020 where he was diagnosed with hypothyroidism. After initiating Ayurvedic treatment further thyroid function was again repeated in February 2021 and June 2021 where TSH was found to be reduced. Laboratory reports are attached in figure no. 1 and results are also compiled in table no. 1. 
Table 1: Thyroid Function Test reports for the case report

\begin{tabular}{|l|l|l|l|}
\hline Test & 01 March 2020 & 15 February 2021 & 21 June 2021 \\
\hline Serum Triiodothyronine T3 & $21.85 \mathrm{ng} / \mathrm{dl}$ & $1.44 \mathrm{ng} / \mathrm{dl}$ & $1.10 \mathrm{ng} / \mathrm{mL}$ \\
\hline SerumThyroxine T4 & $2.05 \mu \mathrm{g} / \mathrm{dl}$ & $8.3 \mu \mathrm{g} / \mathrm{dl}$ & $9.08 \mathrm{ng} / \mathrm{dl}$ \\
\hline $\begin{array}{l}\text { Thyroid Stimulating } \\
\text { Hormone (TSH) }\end{array}$ & $181 \mu \mathrm{IU} / \mathrm{mL}$ & $0.11 \mu \mathrm{IU} / \mathrm{mL}$ & $5.59 \mu \mathrm{IU} / \mathrm{mL}$ \\
\hline
\end{tabular}

Diet

The patient was recommended to avoid non vegetarian food, fast food and milk products. Patient was strictly advised to take seasonal fruits of three to four types before each meal.

\section{Ayurvedic Interventions}

On the basis of clinical diagnosis and laboratory investigations, Ayurvedic medicines having action on thyroid gland and digestion improvement were prescribed. Patient was administered with Ayurvedic medicines described in table no. 2 for the duration of six month of treatment.

Table 2: Ayurvedic medicines prescribed to the patient in this case

\begin{tabular}{|c|c|c|c|c|c|c|}
\hline S.No. & Name of Medicines & Form & Dosage & Route & Adjuvant & Mode of Action \\
\hline 1. & Divya Thyri & Capsule & Twice a day & Oral & $\begin{array}{l}\text { Lukewarm } \\
\text { water }\end{array}$ & $\begin{array}{l}\text { Stimulates normal functioning } \\
\text { of pituitary gland, Kaphaghna, } \\
\text { Medhnashak }\end{array}$ \\
\hline 2. & Divya Liv-ds & Capsule & Twice a day & Oral & $\begin{array}{l}\text { Lukewarm } \\
\text { water }\end{array}$ & $\begin{array}{l}\text { Digestive stimulant, appetizer, } \\
\text { liver modulator, Aampachan, } \\
\text { Pachakghnivardhana }\end{array}$ \\
\hline 3. & Liv-Gain 60 & Tablet & Twice a day & Oral 2 & $\begin{array}{l}\text { Lukewarm } \\
\text { water }\end{array}$ & $\begin{array}{l}\text { Aampachan (helps to keep } \\
\text { digestive system healthy) }\end{array}$ \\
\hline 4. & Maha Amritam & Powder & $\begin{array}{l}\text { Once in a } \\
\text { day }(2.5 \mathrm{gm})\end{array}$ & Oral & $\begin{array}{l}\text { Lukewarm } \\
\text { water }\end{array}$ & $\begin{array}{l}\text { Anulomana, Vatshoolnashaka, } \\
\text { Deepanpachana, treat } \\
\text { digestive disorder, Aamnashak }\end{array}$ \\
\hline 5. & Divyagranthi Harvati & Tablet & Twice a day & Oral & $\begin{array}{l}\text { Lukewarm } \\
\text { water }\end{array}$ & $\begin{array}{l}\text { Helps to reduce or breakdown } \\
\text { deep seated, Kapha dosha \& } \\
\text { supports digestive fire, } \\
\text { Kaphaghna, Shothar, Kleda } \\
\text { shamak. }\end{array}$ \\
\hline 6. & Divyaasthiposhakvati & Tablet & Twice a day & Oral & $\begin{array}{l}\text { Lukewarm } \\
\text { water }\end{array}$ & $\begin{array}{l}\text { Anti-inflammatory, } \\
\text { antioxidant, anti-arthritic, } \\
\text { potent natural calcium } \\
\text { supplement, beneficial for } \\
\text { bones \& joints }\end{array}$ \\
\hline 7. & Dhatu Poshak & Capsule & Twice a day & Oral & $\begin{array}{l}\text { Lukewarm } \\
\text { water }\end{array}$ & $\begin{array}{l}\text { Balya, Rasayana (rejuvenator), } \\
\text { Dhatuposhak }\end{array}$ \\
\hline 8 & $\begin{array}{l}\text { Amla pittahar } \\
\text { churan } 60 \mathrm{gm}\end{array}$ & Powder & $\begin{array}{l}\text { Once a day } \\
\text { before sleep }\end{array}$ & Oral & $\begin{array}{l}\text { Lukewarm } \\
\text { water }\end{array}$ & $\begin{array}{l}\text { Deepan pachan, Pitta Shamak, } \\
\text { Mradu rechan }\end{array}$ \\
\hline 9 & Amlapittanashak cap & Capsule & Twice a day & Oral & $\begin{array}{l}\text { Lukewarm } \\
\text { water }\end{array}$ & $\begin{array}{l}\text { Deepan pachan, Pitta shamak, } \\
\text { Mradu rechan }\end{array}$ \\
\hline 10 & $\begin{array}{l}\text { Shuddhi Karan } \\
\text { tablet }\end{array}$ & Tablet & $\begin{array}{l}\text { Once in } \\
\text { week }\end{array}$ & Oral & $\begin{array}{l}\text { Normal } \\
\text { water }\end{array}$ & Pitta rechak, Shodhan \\
\hline
\end{tabular}

\section{Follow-up and Outcomes}

First follow up of patient was taken after 2 months of treatment, then after one month for the time period of total four months. Recurring of symptoms in the patient was gradually decreased after every month of treatment. Patient was appeared normally clinically after the six-month duration of herbal treatment with no any significant clinical symptom.

\section{OBSERVATIONS AND RESULTS}

The patient was diagnosed with subclinical hypothyroidism. As per his previous reports, the T3 
and T4 level of the patient was $21.85 \mathrm{ng} / \mathrm{dl}$ and $2.05 \mu \mathrm{g} / \mathrm{dl}$ respectively which was within normal biological reference range whereas TSH level was found to be very high i.e. $181 \mu \mathrm{IU} / \mathrm{ml}$ in march 2020 . The patient was prescribed with the Ayurvedic medicines as given in table no.1. After this Ayurvedic medicinal treatment for four months i.e., from November 2020 to February 2021, significant results were noted in terms of reduction in level of increased
TSH. TSH level was significantly reduced from $181 \mu \mathrm{IU} / \mathrm{ml}$ to $0.11 \mu \mathrm{IU} / \mathrm{ml}$ within two months of Ayurvedic treatment. Then, there was a mild increase in the TSH level when patient was tested for TFT after four months i.e. on $21^{\text {st }}$ of June 2021, investigated level of TSH was $5.59 \mu \mathrm{IU} / \mathrm{ml}$. Overall, a satisfactory result was observed in patient clinical conditions. Graphical representation of the result is shown in graph no. 1.

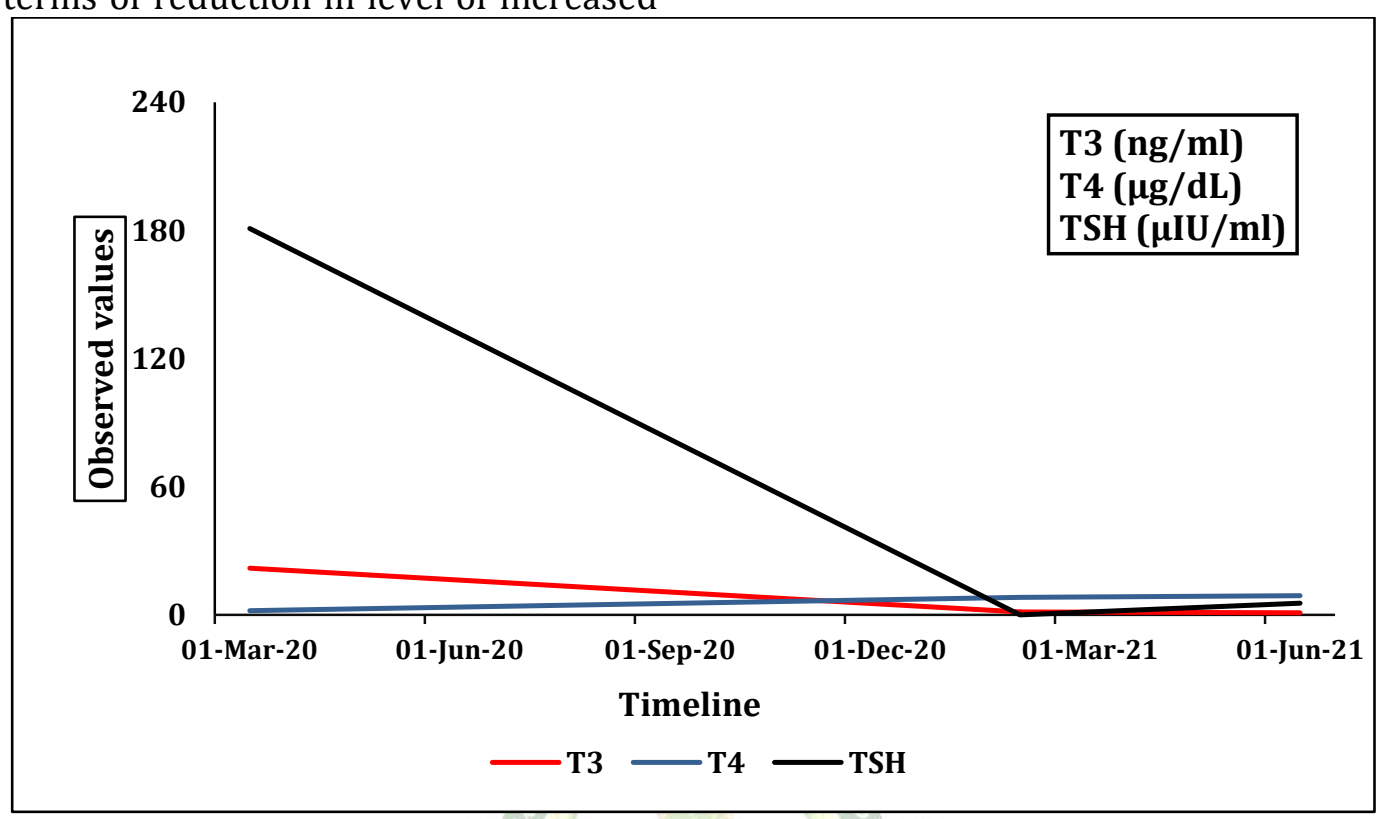

Figure 2: Graph showing Ayurvedic treatment result in reducing TSH

\section{CONCLUSION}

Ayurveda has laid its own principles for the cause, diagnosis, prevention and treatment of diseases. From the above study it can be clearly concluded that Ayurvedic medicines are effective in the management of subclinical hypothyroidism without apparent evidence of any adverse effect or any severe complication in the patient. The condition of hypothyroidism can be very well managed with use and proper selection of Ayurvedic medicines. Also, medicines are well tolerated by the patient without any side effect. So from this case study it was concluded that by adopting traditional Ayurvedic medicines and treatment one can not only decrease the level of TSH in hypothyroidism, but also stimulate the normal functioning of thyroid gland.

\section{ACKNOWLEDGMENT}

Authors are thankful to Acharya Manish Ji for providing opportunity for Shuddhi Ayurveda Clinic doctors for conducting case studies on their patients using Shuddhi Ayurveda herbal medicines.

\section{REFERENCES}

1. Benvenga S, Tuccari G, Ieni A, Vita R. Thyroid gland: anatomy and physiology. Encyclopedia of Endocrine Diseases. 2018 Jan 1:382-90.

2. Ranade AV, Rai R, Pai MM, Nayak SR, Krisnamurthy A, Narayana S. Anatomical variations of the thyroid gland: possible surgical implications. Singapore medical journal. 2008 Oct 1; 49 (10):831.

3. Madan PN, Veena MS. A review on Mundi (Sphaeranthusindicus Linn)-Its medicinal value in Hypothyroidism. Journal of Ayurveda and Integrated Medical Sciences. 2020 Dec 31; 5(06): 134-40.

4. Kadlaskar BB, Ravindranath L. Hypothyroidism in Ayurveda- A Conceptual Study. Ayushdhara. 2015; 2(4): 246-50.

5. Bansode NM. "Hypothyroidism" In an Ayurvedic Perspective Review. Aayushi International Interdisciplinary Research Journal. 2018; 5(1):13336.

6. Ralston SH, Penman ID, Strachan MW, Hobson R, editors. Davidson's Principles and Practice of Medicine E-Book. Elsevier Health Sciences; 2018 Feb 2.

7. Smith JW, Evans AT, Costall B, Smythe JW. Thyroid hormones, brain function and cognition: a brief review. Neuroscience \& Biobehavioral Reviews. 2002 Jan 1; 26(1):45-60.

8. Tortora GJ, Derrickson BH. Principles of anatomy and physiology. John Wiley \& Sons; 2018 May 15. 
9. Biban BG, Lichiardopol C. Iodine deficiency, still a global problem? Current health sciences journal. 2017 Apr; 43(2):103.

10. Fauci AS. Harrison's principles of internal medicine. Mc Graw-Hill Education; 2015.

11. Warrell DA, Cox TM. John D. Firth Oxford Textbook of Medicine, 4th Edi. Oxford textbook of medicine. 2010; 2:1990.

12. Boon NA. Davidson's principles and practice of medicine. Churchill Livingstone; 2006 Jun 1.

13. Balikai V, Chavan SG, AS P. A Critical Review of Subclinical Hypothyroidism in Ayurveda. Journal of Ayurveda and Integrated Medical Sciences. 2016 Dec 31; 1(04):123-7.

14. Jagmeet K, Milan C. Kanchnar Guggulu and Varunadi Kashaya in Hypothyroidism- A Case Study. Int. J. Ayur. Pharma Research. 2014;2(2):5860.

15. Panthi S, Gao T. Diagnosis and management of primary hypothyroidism in Traditional Chinese medicine (TCM) and Traditional Indian Medicine (Ayurveda). Int J Clin Endocrinol Metab 1 (1): 009. 2015; 12(009).
16. Dubey N, Ekta JR, Bora GK, Rao BC, Srikanth N. Efficacy and Safety of Ayurveda Interventions for Hypothyroidism in 18 to 60 Years' Age-group: A Systematic Review Protocol. Journal of Research in Ayurvedic Sciences. 2019; 3(3):112-16.

17. Singh K, Thakar AB. A clinical study to evaluate the role of Triphaladya Guggulu along with Punarnavadi Kashaya in the management of hypothyroidism. Ayu. 2018 Jan; 39(1):50.

18. Kakkassery A, Krishnan P, Varghese PR. Effective Ayurveda therapy to treat thyroid disorders. Journal of Ayurvedic and Herbal Medicine. 2019; 5(1):10-2.

19. D Khadtale DA, Vaidya MS. Effect of Ayurvedic Drug Combination in Management of HypothyroidismA Case Study. International Journal of ResearchGranthaalayah. 2020 Aug 17; 8(7):410-4.

20. Kundu D, Rekha D, Anup B. Hypothyroidism-A Case Report. Journal of Ayurveda and Integrated Medical Sciences. 2017 Jun 30; 2(03):287-90.

21. Kaur A, Verma SK, Kalsi S. Hypothyroidism: Management Based On Ayurvedic and Modern Therapeutic Perspective. International Journal of Pharmaceutics and Drug Analysis. 2016 Jun 20; 4(6): 281-8.

\section{Cite this article as:}

Bhawna Walia, Manish Grover, Ajeet Pratap Singh. Effective Management of Hypothyroidism By Using Ayurvedic Interventions: A Case Report. International Journal of Ayurveda and Pharma Research. 2021;9(8):40-45.

https://doi.org/10.47070/ijapr.v9i8.1976

Source of support: Nil, Conflict of interest: None Declared

Disclaimer: IJAPR is solely owned by Mahadev Publications - dedicated to publish quality research, while every effort has been taken to verify the accuracy of the content published in our Journal. IJAPR cannot accept any responsibility or liability for the articles content which are published. The views expressed in articles by our contributing authors are not necessarily those of IJAPR editor or editorial board members. 